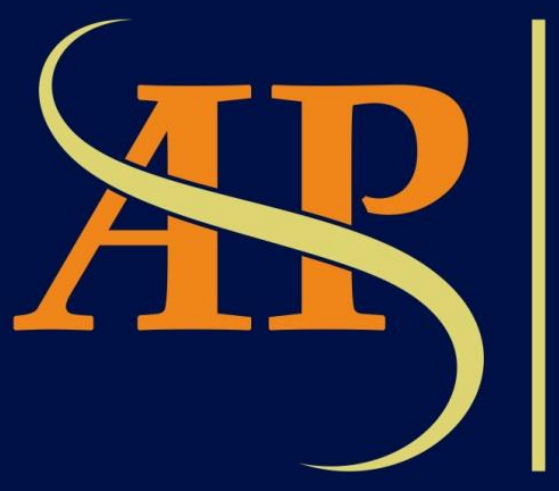

JURNAL ASIA PACIFIC STUDIES

Journal of International Relations Study Program Faculty of Social and Political Sciences

Universitas Kristen Indonesia

Volume 2 | Number 2 | July - December 2018 


\title{
MENGKAJI PERAN UN WOMEN DALAM MENGATASI KEKERASAN TERHADAP PEREMPUAN DAN MEWUJUDKAN KESETARAAN GENDER MELALUI PERSPEKTIF FEMINISME
}

\author{
${ }^{1}$ Iqbal Ramadhan; ${ }^{2}$ Innesia Ma’sumah \\ ${ }^{12}$ Program Studi Hubungan Internasional,Universitas Pertamina, Jl. Teuku Nyak Arief, Simprug, Grogol Selatan, \\ Jakarta Selatan, Daerah Khusus Ibukota Jakarta \\ 1iqbal.ramadhan@universitaspertamina.ac.id; $;$ Innesia98@yahoo.com
}

\begin{abstract}
This research discusses about the role and effectiveness of UN Women as the real implementation of the Feminist paradigm and as an International Organization that upholds women's right in solving important issues related to women's rights, like violence against women and gender inequality. To analyse the issue on this journal, authors uses gender concept and feminist securitical approach. It also gives a stand point about the two main paradigms of International Relations, Realist and Liberalist, and its relation to Feminists regarding gender inequality and violence on women. The result of this research is that UN Women is quite effective in dealing with Feminist issues although it has not experienced significant improvement. However, UN Women's efforts should be appreciated for fighting for women's rights.
\end{abstract}

Keywords: UN Women, Feminist, Violence against Women, Gender Inequality

\begin{abstract}
Abstrak
Penelitian ini membahas tentang peran dan efektivitas UN Women sebagai implementasi nyata dari paradigma Feminis dan merupakan Organisasi Internasional yang menjunjung tinggi hak perempuan dalam menyelesaikan isu-isu penting terkait dengan perempuan yaitu kekerasan terhadap perempuan dan ketimpangan gender. Dalam menganalisis isu pada jurnal ini, penulis menggunakan konsep gender dan pendekatan keamanan feminis. Penelitian ini juga memberikan kritik terhadap dua paradigma utama Hubungan Internasional yaitu Realis dan Liberalis dalam keterkaitannya dengan Feminis terkait ketimpangan gender dan kekerasan terhadap perempuan. Hasil dari penelitian ini adalah UN Women cukup efektif dalam menangani isu-isu Feminis walaupun belum mengalami peningkatan yang signifikan. Namun upaya UN Women harus diapresiasi karena telah memperjuangkan hak perempuan.
\end{abstract}

Kata Kunci: UN Women, Feminis, Kekerasan terhadap Perempuan, Ketimpangan Gender 


\section{Pendahuluan}

Setelah berakhirnya Perang Dunia II banyak muncul International Organizations dengan harapan dapat memberikan keamanan serta membawa perdamaian di dunia dan tentu untuk mencegah kedua perang seperti yang sebelumnya terjadi lagi. Salah satu organisasi yang muncul tepat saat berakhirnya Perang Dunia II adalah The United Nations atau Perserikatan Bangsa-Bangsa yang diresmikan pada tanggal 24 Oktober 1945 yang pada saat itu beranggotakan dan diwakili oleh 50 negara pada United Nations Conference on International Organization di San Francisco, Amerika Serikat. UN sendiri memiliki beberapa organisasi kecil di bawahnya atau program yang masing-maing memiliki fokus terhadap permasalahan yang akan ditangani.

Salah satu organisasi atau program di bawah UN adalah UN Women. Ini merupakan organisasi UN yang didedikasikan untuk kesetaraan gender dan pemberdayaan perempuan. Tujuan ini tentu sejalan dengan Sustainable Development Goals (SDG) yang kelima yaitu mencapai Gender Equality atau kesetaraan gender (UN Women n.d). Dalam mewujudkan tujuan ini, UN Women bekerjasama dengan pemerintah dan tentunya masyarakat sipil dalam merancang hukum, kebijakan, program, dan layanan yang diperlukan untuk memastikan bahwa kebutuhan perempuan dan anak-anak terakomodasi dengan baik di dalamnya dan partisipasi perempuan yang setara dengan semua aspek kehidupan.

Selain itu, UN Women mempunyai fokus dengan lima bidang prioritas (n.d), yang pertama adalah increasing women's leadership and participation, ini tentu berkaitan erat dengan kesetaraan gender mengingat budaya patriarki masih sangat kental di beberapa negara. Fokus kedua adalah ending violence against women terkait dengan masih banyak perempuan dan anak-anak yang menjadi korban karena kekerasan baik fisik maupun psikis yang dilakukan oleh laki-laki. Fokus yang ketiga adalah engaging women in all aspects of peace and security processes karena perempuan kerap kali menjadi korban dari konflik maupun perang, maka dari itu UN Women ingin melibatkan partisipasi perempuan dalam pengambilan keputusan untuk mencegah dan menyelesaikan konflik. Fokus keempat adalah enhancing women's economic empowerment dimana perempuan sangat berkontribusi dalam ekonomi, bisnis, bahkan pertanian sebagai pengusaha ataupun karyawan, namun ini tidak sejalan dengan upah perempuan yang cenderung lebih kecil dan kehidupan perempuan tidak menjadi lebih baik. Fokus terakhir adalah making gender equality central to national development planning and budgeting dimana peran perempuan dalam tata kelola dan perencanaan nasional dapat menjadi cara tercepat untuk mewujudkan kesetaraan gender. Dengan fokus dalam lima bidang prioritas ini, dapat dilihat bahwa kembali lagi ke tujuan utama dibentuknya UN Women adalah untuk mewujudkan gender equality dan menghapuskan pandangan bahwa perempuan hanya sekedar komoditas atau bahkan subordinate untuk laki-laki.

Dengan ini dapat diketahui bahwa kesetaraan gender merupakan salah satu aspek vital dalam sistem maupun struktur internasional. Maka dari itu fokus dalam penelitian ini menitikberatkan pada tiga aspek yaitu bagaimana dua paradigma utama Ilmu Hubungan Internasional yaitu realisme dan liberalisme dalam memandang eksistensi UN Women mengingat kedua paradigma tersebut adalah paradigma yang dinilai sangat kental dengan patriarki dan terlalu maskulin. Selain itu, dua mahzab teresebut akan dikaji dari sudut pandang feminis. Terkait dengan feminis itu sendiri, paradigma yang sangat mengedepankan perempuan muncul atas kritik terhadap realisme dan liberalisme. Selanjutnya yang akan dibahas dalam penelitian ini adalah peran UN Women dalam mengatasi kekerasan terhadap perempuan. Seperti yang telah tercantum dalam salah satu fokus lima bidang prioritas yaitu ending violence against women sudah pasti banyak kontribusi UN Women dalam mengatasi 
isu kekerasan, namun yang akan dibahas ini adalah mengenai keefektifan UN Women. Selain keefektifan dalam mengatasi kekerasan terhadap perempuan, penelitian ini juga akan menitikberatkan pada peran UN Women dalam kesetaraan gender itu sendiri dan usahanya dalam mengatasi ketimpangan terutama di negara-negara yang merupakan middle power.

\section{Gender dalam Feminisme}

Feminis adalah pandangan yang lahir sebagai kritik atas paradigma realis dan liberalis yang dinilai terlalu maskulin. Realis adalah paradigma yang memiliki ide dan asumsi dasar seperti pesimis terhadap sifat manusia, hubungan antar negara yang konfliktual harus diselesaikan dengan perang, serta keamanan nasional dan kelangsungan hidup negara adalah hal utama (Jackson and Sorensen 2013). Sedangkan liberalisme adalah paradigma yang merupakan kebalikan dari realisme. Jika kaum realis cenderung pesimis, kaum libelarisme memiliki pandangan positif tentang sifat manusia dan yakin bahwa manusia adalah makhluk yang rasional dan dapat menyelesaikan masalah-masalah internasional dengan cara bekerjasama atau kooperatif (Jackson and Sorensen 2013).

UN Women sendiri adalah organisasi yang sangat mengedepankan peran dan kepentingan perempuan, maka dari itu akan sangat relevan apabila paradigma yang digunakan sebagai teori dasar penelitian ini adalah paradigma feminisme. Feminisme adalah pendekatan yang fokus pada ketidaksetaraan dasar antara laki-laki dan perempuan serta konsekuensi ketidaksetaraan tersebut untuk politik dunia (Jackson and Sorensen 2013). Bagaimana ini dapat memengaruhi politik dunia dapat dilihat dengan adanya ketergantungan pada kontrol kaum laki-laki terhadap perempuan. Selain itu, hubungan laki-laki dan perempuan terletak pada definisi konvensional antara 'maskulinitas' dan 'feminitas' yang secara tidak langsung menempatkan perempuan lebih rendah daripada laki-laki (2013).

Sedangkan dalam buku International Relations: Perspectives, Controversies, and Readings $4^{\text {th }}$ Edition yang ditulis oleh Keith L. Shimko dikatakan bahwa feminisme adalah perspektif tentang fenomena sosial yang berfokus pada isu-isu yang menjadi perhatian perempuan sementara secara teoritis menekankan pada pentingnya gender (2013). Shimko juga mengatakan bahwa ketika feminis melihat dunia, ketidaksetaraan gender dan dominasi laki-laki terlihat sangat jelas.

Feminisme pertama kali muncul dan menjadi bagian dari disiplin Ilmu Hubungan Internasional pada sekitar akhir tahun 1980 dan awal tahun 1990 (Tickner and Sjoberg 2016). Menurut buku International Relations Theory: Discipline and Diversity, kaum feminis awalawal mencoba menantang disiplin Ilmu Hubungan Internasional yang lain untuk memikirkan bagaimana teorinya dapat dirumuskan kembali dan bagaimana pemahaman tentang politik global dapat ditingkatkan jika lebih diberikan perhatian terhadap pengalaman perempuan. Tickner dan Sjoberg juga bahwa feminis mendefinisikan gender sebagai serangkaian karakteristik yang dibentuk melalui konstruksi sosial (socially constructed) yang menggambarkan bagaimana laki-laki dan perempuan seharusnya berperilaku. Karakteristik ini seperti kuat, rasional, dan bebas yang terkait erat dengan maskulinitas, sedangkan lemah, emosional, dan relasional dikaitkan dengan karakteristik perempuan (2016).

Titik asumsi dasar feminisme menitikberatkan pada peran "gender" (Viotti and Kauppi 2014). Menurut pandangan feminisme, gender memainkan peran penting tidak hanya di ranah rumah tangga tetapi juga kancah politik internasional. Seperti yang dipaparkan oleh Viotti dan Kauppi bahwa teori-teori besar gagal dalam menangkap isu yang berada di tingkat individu. Selain itu, teori besar seperti realisme dan liberalisme cenderung mengabaikan 
ketimpangan gender yang terlalu berfokus pada budaya patriarki (Viotti and Kauppi 2014). Asumsi besar lainnya yang dipaparkan oleh kaum feminisme adalah pengembangan emansipasi perempuan dengan menghapuskan ketimpangan gender yang diakibatkan oleh budaya patriarki. Menurut asumsi feminisme, ketimpangan gender tersebut luput dari pandangan mahzab besar seperti realisme. Adapun sebagian besar feminisme menolak metodologi positivisme dan memilih menggunakan pendekatan konstruktivis bahwa pengetahuan dibentuk oleh konstruksi budaya, sejarah dan konteks (Viotti and Kauppi, 2014).

Selain itu, salah satu yang juga menjadi kajian utama feminisme ialah peran domestik yang dimainkan oleh perempuan. Dalam buku A Cultural History of Women in the Modern Age, dinyatakan bahwa perempuan, terutama yang telah berkeluarga, harus menyalurkan perhatiannya pada urusan domestik, yakni pekerjaan rumah dan anak-anak. Walaupun begitu, dari dekade ke dekade, pandangan mengenai peran perempuan yang tidak hanya pada ranah domestik melainkan pada politik praktis, telah mulai dipertimbangkan banyak orang. Ketimpangan dan diskriminasi kerap kali dirasakan karena partisipasi perempuan dalam sektor ekonomi dengan menjadi buruh, umumnya harga dihargai dengan upah yang kecil, terlepas dari beban pekerjaan yang sama seperti yang dilakukan oleh laki-laki. Hal ini yang kemudian pelatuk akan terciptanya gerakan-gerakan perempuan yang mempertanyakan nilai dan norma mereka dalam kehidupan sosial (Hannam 2016).

Dengan kehadiran UN Women, permasalahan yang menjadi kekhawatiran utama kaum feminis yaitu menghapuskan ketimpangan antara laki-laki dan perempuan harusnya dapat teratasi. Berdasarkan penelitian terdahulu dari The Organisation for Economic Cooperation and Development dengan judul Development Effectiveness Review of the United Nations Entity for Gender Equality and the Empowerment for Women (UN Women) yang dilakukan selama 3 tahun dari tahun 2011 sampai 2014 dan diterbitkan pada tahun 2015, dijelaskan bahwa hampir $80 \%$ evaluasi mengenai kesetaraan gender yang dilakukan UN Women memberikan hasil yang positif dan memuaskan. Faktor kunci keberhasilan ini terdapat pada program-program yang sejalan dengan kesetaraan gender dan pemberdayaan perempuan yang juga juga tercermin dalam pendekatan yang berbasis hak asasi manusia (OECD 2015). Dalam perspektif gender, dari hasil penelitian tersebut dinyatakan bahwa eksistensi UN Women sebagai organsisasi internasional yang memiliki fokus untuk mengafirmasi peran perempuan, telah efektif dan secara perlahan, mampu mengatasi kekhawatiran perempuan di negara-negara yang masih kental dengan krisis gender. Seperti yang terjadi di Mali dan Sierra Laone di mana program yang dicanangkan oleh UN Women berhasil meningkatkan akses perempuan dalam layanan hukum dan paralegal yang terdesentralisasi.

Dijelaskan juga dalam studi kasus lain dengan penelitian berjudul Evaluation of $U N$ Women's Contribution to Increasing Women's Leadership and Participation in Peace and Security and Humanitarian Response dalam Headquarter and Global Case Study (Domingo 2013) bahwa peralihan UN Women dan mandat barunya untuk menciptakan ruang politik dan keterlibatan yang lebih efektif di tingkat pusat menunjukan peningkatan yang signifikan, baik peran koordinasi dalam UN itu sendiri maupun yang terkait dengan aktor antar pemerintah. Selain peningkatan yang signifikan, koordinasi di bidang perempuan, perdamaian, dan keamanan juga terjadi pergeseran intensitas, menghasilkan kemitraan yang lebih baru, lebih dekat, dan lebih sinergis dengan entitas UN lainnya yang keterlibatannya juga penting untuk mewujudkan kemajuan dalam tujuan perdamaian dan keamanan (Domingo 2013). Menurut Domingo, salah satu yang perlu menjadi fokus utama dalam UN Women ialah organisasi ini perlu lebih terlibat dalam forum kebijakan internasional karena perspektif gender masih 
sangat tertinggal dan tidak dijadikan fokus utama dalam proses pembuatan keputusan ataupun kebijakan. UN Women tentu memiliki cukup kapabilitas untuk membuat perbedaan bagi perempuan dalam ranah politik praktis. Mengacu pada aspek novelty (kebaruan), penelitian pada jurnal ini akan fokus membahas tentang stand point feminisme dalam mengkaji target (indikator) UN Women dalam mengatasi kekerasan terhadap perempuan dan aktivitasnya mengurangi kesenjangan gender yang ada di dunia.

\section{Pendekatan Feminisme dalam Studi Keamanan}

Studi keamanan dalam studi Hubungan Internasional pada awalnya masih menitikberatkan pada sektor keamanan dan politik (Buzan, 1998). Ini tidak terlepas dari pendekatan state-centric yang masih mewarnai tatanan politik dunia yang saat itu masih terpusat pada polaritas dua kekuatan dunia. Studi keamanan semakin populer ketika Barry Buzan menelurkan pemikirannya dalam buku berjudul People, State and Fear (Williams, 2013). Pemikiran Buzan tersebut mengklasifikasikan tipologi keamanan ke dalam lima sektor yaitu military, political, societal, economics dan environmental.

Dalam studi keamanan ini, Buzan sendiri membagi bentuk ancaman sesuai dengan sektornya masing-masing. Definisi ancaman itu sendiri memiliki banyak definisi. Pada umumnya ancaman dapat diartikan sebagai segala sesuatu yang menghalangi individu ataupun organisasi mencapai tujuannya (Buzan 1998). Ancaman yang muncul di sektor militer adalah invasi, sedangkan pada sektor politik ancaman dapat berupa militer. Adapun ancaman yang datang dari sektor lingkungan dapat berupa bencana alam. Ancaman yang umumnya muncul pada sektor ekonomi adalah inflasi dan ancaman terhadap identitas atau hilangnya nilai-nilai budaya merupakan bentuk ancaman dari sektor sosial. Kemunculan ancaman tidak bisa dimungkiri berpengaruh terhadap referent object atau entitas yang terancam karena adanya ancaman tersebut.

Pendekatan feminisme dalam studi keamanan semakin marak pasca Perang Dingin berakhir. Hal ini sangat berkaitan dengan pergeseran transformasi isu dan aktor dalam studi Hubungan Internasional yang semakin beragam dan kompleks (Withworth dalam Williams 2013). Pengkaji feminisme dalam studi keamanan menjelaskan bahwa rasa aman dan tidak aman sangat erat relevansinya dengan gender. Karena adanya ketimpangan gender, tatanan sosial menempatkan posisi pria di atas perempuan yang memunculkan sebuah budaya patriarki (Withworth dalam Williams 2013). Budaya patriarki ini pada dasarnya mengancam identitas perempuan karena rentan penyalahgunaan wewenang. Pengkaji feminisme melihat bahwa budaya patriarki ini pada dasarnya akan mendorong aktivitas direct violence yang pada akhirnya melahirkan tindakan kekerasan pada perempuan (Withworth dalam Williams 2013).

Mengacu pada pendekatan feminisme dalam studi keamanan, perempuan pada dasarnya menjadi referent object. Ancaman atau threat dapat berupa budaya patriaki yang mengendalikan kebebasan hidup perempuan dan ketimpangan gender yang pada hakikatnya menghalangi hak-hak perempuan sebagai manusia (Withworth dalam Williams 2013). Kehadiran ancaman ini tentu memiliki dampak yang sangat besar terhadap tatanan sosial khususnya perempuan. Salah satu dampak besarnya adalah menjadikan perempuan sebagai objek seksual dan kekerasan yang berlaku tidak hanya di medan perang, namun juga di dalam kehidupan sehari-hari (Withworth dalam Williams 2013). Pada penelitian ini, pendekatan keamanan digunakan untuk mengkaji peran UN Women memitigasi ancaman terhadap referent object dalam hal ini adalah perempuan. 


\section{Kritik terhadap Realisme}

Salah satu pandangan utama dan merupakan pandangan tertua dalam diskursus Ilmu Hubungan Internasional, realisme menekankan bahwa negara adalah unitary actor atau satusatunya aktor yang penting dalam Hubungan Internasional. Tidak heran seorang realis akan mendefinisikan keamanan yang harus diutamakan adalah keamanan negara. Negara yang aman adalah negara yang dapat melindungi batas-batas fisik dan moralnya terhadap sistem internasional yang 'anarki'. Salah satu asumsi realis yang ditentang keras oleh kaum feminis adalah asumsi mengenai negara yang merupakan aktor satu-satunya, maka struktur dan kebijakan internalnya tidak begitu penting dibanding kondisi anarkis yang menyangkut keamanan dan ketidakamanan negara (Tickner and Sjoberg 2016).

Disini yang dicoba dikritik dan ditentang oleh kaum feminis adalah asumsi keamanan menurut realis yang terlalu state-centric padahal ancaman yang dialami individu juga harus diutamakan. Ancaman seperti kekerasan domestik, pemerkosaan, kemiskinan, subordinasi gender, dan kerusakan lingkungan tidak kalah penting dengan ancaman perang (Tickner and Sjoberg 2016). Keamanan individu yang coba ditekankan oleh kaum feminis adalah keamanan perempuan dan anak-anak perempuan yang ketika negara dan negara lain berkonflik bahkan berperang, perempuan dan anak-anak yang akan menjadi korbannya. Bukan hanya itu, ketika dalam kondisi tidak perang pun, keamanan perempuan tidak pernah menjadi prioritas untuk ditangani dan selalu menjadi prioritas sekunder. Sebut saja kejahatan seperti kekerasan, pelecehan, perbudakan, dan human trafficking yang mayoritas korbannya adalah perempuan. Hal ini masih terkait erat dengan asumsi masyarakat terhadap perempuan yang seringkali dinilai lemah dan subordinasi laki-laki. Asumsi ini juga berkembang karena pandangan kaum realis dimana laki-laki harus pergi berperang untuk mempertahankan sovereignty atau keamanan negaranya dan perempuan hanya dapat berdiam diri di rumah. Bukan hanya itu, realis bahkan melihat perempuan sebagai 'alat'yang dapat digunakan untuk melawan musuh ketika perang. Ini yang dinamakan sexual violence as a weapon dimana perempuan dijadikan alat untuk menganggu psikologis musuh ketika berperang.

Realis tentu akan menolak eksitensi organisasi UN Women mengingat negara adalah satu-satunya aktor yang memegang peran vital dalam sistem internasional. Aktor lain seperti organisasi internasional, institusi, dan individu bukanlah bagian dari sistem internasional. Bukan hanya itu, fokus UN Women pada keamanan individu juga sangat bertolakbelakang dengan asumsi realis yang menekankan keamanan hanya pada keamanan negara saja melalui peningkatan militer agar dapat bertahan hidup dalam dunia yang anarki ini. Maka dari itu, tidak heran jika realis akan menolak eksistensi UN Women. Walaupun demikian, realis sendiri terkesan mengabaikan ketimpangan-ketimpangan terhadap perempuan karena lebih mengutamakan state security ketimbang human security.

\section{Kritik Terhadap Liberalisme.}

Bukan hanya realis, pandangan lain dalam diskursus Ilmu Hubungan Internasional yang juga menjadi kritik kaum feminis adalah pandangan liberalisme. Sama halnya dengan realis, liberalis merupakan salah satu pandangan tertua dan utama dalam usaha mempelajari hubungan internasional. Keduanya adalah pandangan yang aktor satu-satunya adalah negara dan fokus utamanya adalah interaksi antar negara. Jika seorang realis akan cenderung pesimis dalam memandang sistem internasional karena asumsi utamanya yaitu human nature is bad, 
seorang liberalis akan lebih optimis dan sangat mengedepankan hubungan kerjasama antar negara. Liberalisme juga beranggapan bahwa dengan adanya kerjasama dapat menciptakan harmoni dalam sistem internasional.

Terkait dengan bagaimana liberalis melihat UN Women, feminis juga memiliki kritik sendiri terhadap liberalisme. Seperti yang dikatakan oleh Richard C. Sinopoli and Nancy J. Hirschmann dalam jurnalnya yang berjudul Feminism and Liberal Theory bahwa "There is a structural gender bias in liberal political thought (at least in the social contract tradition) deriving from a liberal conception of the self as an abstract, atomistic individual choosing principles of justice." (Hirschmann 1989). Paradigma liberalis dinilai terlalu bias dengan maskulinitas karena menurut Hirschmann terdapat hubungan antara konsep liberal tentang diri dan pembentukan identitas laki-laki, walaupun dalam jurnalnya Hirschmann tidak mengatakan secara jelas apa hubungan tersebut.

Maskulinitas dalam paradigma liberalisme dapat dilihat sama seperti cara realis memandang sistem atau struktur internasional dimana aktor utamanya adalah negara dan kepentingan individu selalu dikesampingkan. Apalagi mengingat liberalisme adalah paradigma yang sangat mementingkan kerjasama antar negara demi meningkatkan sektor perekonomian. Dalam mewujudkan peningkatan atau pertumbuhan ekonomi tersebut seringkali hak-hak individu, khususnya hak-hak buruh perempuan tidak diperhatikan. Bahkan terdapat kesenjangan yang sangat signifikan antara upah buruh laki-laki dengan upah buruh perempuan. Dalam situs Focus on Labour Exploitation dikatakan bahwa berdasarkan penelitian yang dilakukan oleh TUC (Trades Union Congress) ternyata selain kesenjangan antara upah laki-laki dan perempuan, lebih dari separuh pekerja perempuan juga telah mengalami beragam bentuk pelecehan seksual dan satu dari sepuluh perempuan mengalami kontak seksual yang tidak diinginkan (Falconer 2017). Tentu diskriminasi dan eksploitasi terhadap perempuan ini sangat tidak sebanding mengingat pekerjaan yang dilakukan oleh buruh perempuan tidak lebih mudah dari pekerjaan yang dilakukan oleh buruh laki-laki, namun hak yang diterima keduanya berbeda, yang kemudian menimbulkan disparitas.

Jika dilihat lebih dalam, liberalisme memiliki peran dalam diskriminasi dan ekspolitasi terhadap perempuan. Terkait dengan fokus utama liberalisme yang merupakan meningkatkan perekonomian negara dan salah satu indikasinya adalah semakin menjamurnya pabrik-pabrik di suatu negara. Ini yang kemudian berdampak pada munculnya buruh-buruh berupah rendah, tidak terkecuali buruh perempuan, demi menekan biaya atau cost untuk mencapai keuntungan sebesar-besarnya. Apabila kaum liberalis tidak terlalu ambisius dalam meningkatkan perekonomian negara dan sadar bahwa ada aktor lain yang juga sama pentingnya dengan negara, diskriminasi dan eksploitasi ini tentu tidak akan terjadi. Tentunya, hal ini tidak terlepas dari kritik kaum feminis. Eksploitasi ekonomi pada dasarnya memaksa perempuan sebagai bagian dari masyarakat yang tereksploitasi.

Di sisi lain, liberalisme menekankan pula pada kerja sama internasional yang berorientasi pada institusi internasional. Asumsi dasar mereka adalah kesenjangan kepentingan dan konflik dapat diredakan melalui legalitas organisasi internasional. Walaupun begitu, feminis menjelaskan bahwa keberadaan organisasi internasional tersebut tidak boleh melupakan peran perempuan di dalamnya. Seperti yang telah dijelaskan pada bab teori, feminis liberal mengedepankan emansipasi perempuan dalam bidang ekonomi. Melalui peran organisasi internasional, seperti UN Women, ketimpangan-ketimpangan ekonomi ataupun diskriminasi terhadap perempuan dapat teratasi. 


\section{UN Women dalam Mengatasi Kekerasan terhadap Perempuan}

Kekerasan terhadap perempuan masih menjadi concern utama masyarakat dunia. Pandangan bahwa perempuan hanya sebagai komoditas dan subordinasi kaum laki-laki masih sangat kental dalam budaya masyarakat. Pandangan ini tentu berujung pada anggapan bahwa perempuan adalah makhluk yang lemah dan lebih rendah dibanding laki-laki, atau disebut dengan budaya patriartki. Menurut London Feminist Network (n.d), patriarki adalah istilah yang digunakan untuk menggambarkan masyarakat di mana kita hidup sekarang, ditandai dengan power yang tidak setara antara laki-laki dan perempuan dimana perempuan cenderung systematically disadvantaged and oppressed. Patriarki ditandai dengan kekerasan yang dilakukan laki-laki terhadap perempuan, seperti perempuan dalam kelompok minoritas yang mengalami berbagai penindasan dalam masyarakat.

Mengacu pada data yang dikeluarkan oleh UN Women sendiri bahwa organisasi internasional memiliki target untuk mengeliminasi kekerasan terhadap perempuan. Dua target yang disoroti oleh peneliti adalah eliminate all forms of violence against all women and girls in the public and private spheres,including traffcking and sexual and other types of exploitation dan eliminate all harmful practices,such as child,early and forced marriage and female genital mutilation (UN Women 2015). Alasan peneliti memasukkan dua target tersebut terlepas dari sekian banyak target yang ingin dicapai oleh UN Women adalah kedua target di atas merupakan prioritas utama dan tergolong ke dalam kategoria Tier 1 serta Tier 2 (UN Women 2015). Berdasarkan pada dua target di atas, peneliti akan mengkaji apakah target tersebut tercapai dan berhasil dilaksanakan oleh UN Women sendiri.

Bahkan menurut World Health Organization (WHO), sekitar 1 dari 3 (35\%) perempuan di seluruh dunia telah mengalami kekerasan fisik atau seksual baik dari pasangan maupun bukan pasangan mereka. Lalu 30\% diantaranya mengalami kekerasan dari pasangan mereka. Laki-laki lebih mungkin melakukan kekerasan jika memiliki pendidikan rendah, riwayat penganiayaan anak, dan penggunaan alkohol. Salah satu faktor yang sangat berpengaruh adalah masih terdapat norma-norma gender di kalangan masyarakat seperti perempuan 'pantas' menerima kekerasan dari pasangannya dan 'hak istimewa' yang dimiliki laki-laki.

Norma-norma gender di kalangan masarakat inilah yang seringkali dijadikan justifikasi atas kekerasan laki-laki terhadap perempuan. Tidak dapat dipungkiri dalam beberapa hal memang laki-laki memiliki power dan kedudukan di atas perempuan, seperti misalnya dalam rumah tangga, namun ini tetap tidak dapat dijadikan pembenaran atas kekerasan domestik yang seringkali terjadi. Segala bentuk kekerasan yang dilakukan terhadap perempuan seperti penganiayaan dan penindasan dapat dikategorikan sebagai bentuk pelanggaran terhadap Hak Asasi Manusia (HAM). Bagaimanapun setiap manusia memiliki hak yang sama terlepas dari gender yang dimilikinya. Selain itu, kekerasan terhadap perempuan juga memengaruhi politik suatu negara karena produktivitas negara akan turun dan akan ada biaya hukum yang berdampak pada anggaran nasional dan pembangunan secara keseluruhan.

UN Women sendiri telah melakukan beberapa usaha untuk menghapuskan kekerasan terhadap perempuan. Sesuai dengan perjanjian internasional yaitu Convention on the Elimination of All Forms of Discrimination against Women dan yang tercantum pada $U N$ Declaration on the Elimination of Violence against Women tahun 1993 (UN Women n.d), UN Women bekerjasama dengan negara-negara dalam tingkat global untuk memajukan kerangka normatif internasional melalui dukungan yang diberikan kepada proses antar pemerintah, 
seperti General Assembly dan CSW (Commission on the Status of Women). Lembaga CSW sendiri adalah badan antar pemerintah global yang khusus didedikasikan untuk mempromosikan kesetaraan gender dan pemberdayaan perempuan. Sedangkan dalam tingkat negara, UN Women mendukung pemerintah dalam mengadopsi dan memberlakukan reformasi hukum yang selaras dengan standar internasional. Salah satu program UN Women dalam mengatasi kekerasan adalah program 'Safe Cities Free of Violence against Women and Girls' (UN Women n.d). Program ini didirikan di negara seperti Ekuador, Mesir, India, Rwanda, dan beberapa negara lainnya. Program ini dapat membantu mengatasi kekerasan dan mencegah pelecehan seksual, terutama di ruang publik. Dengan semakin meningkatnya awareness masyarakat mengenai kekerasan terhadap perempuan sebagai bentuk pelanggaran HAM yang berat, akan berkembang pula pemahaman masyarakat bahwa perempuan bukan sekedar komoditas dan subordinasi laki-laki yang pantas diperlakukan dengan kekerasan.

Langkah UN Women lainnya dalam mengatasi kekerasan terhadap perempuan adalah mengembangkan edukasi kurikulum dengan menggandeng World Association of of Girl Guides and Scouts (UN Women n.d). Pengembangan kurikulum tersebut menyasar perempuan dengan rentang usia 5 hingga 25 tahun. Lembaga tersebut menyatakan dalam situs resminya bahwa program tersebut diselenggarakan dengan cara menggandeng negara di beberapa regional yang selanjutnya mereka akan melakukan advokasi terkait jenis-jenis kekerasan yang sering dialami oleh perempuan. Program lainnya yang dikembangkan oleh UN Women adalah Partner for Prevention (P4P). UN Women menyelenggarakan program $\mathrm{P} 4 \mathrm{P}$ dengan cara joint cooperation bersama UN dengan pemberian edukasi pada pria dan lakilaki (UN Women n.d). Program tersebut terbilang unik karena laki-laki yang sering diidentikkan dengan budaya patriarki mendapatkan pemahaman tentang budaya kekerasan yang sering terjadi pada perempuan.

Terlepas dari program-program strategis yang dibangun oleh UN Women, kita perlu melihat apakah program tersebut berjalan efektif serta dapat memitigasi ancaman terhadap referent object paling utama dalam penelitian ini yaitu perempuan. Tabel berikut di bawah ini menggambarkan persentase kekerasan terhadap perempuan di belahan wilayah dunia. 


\section{FIGURE 3.8}

\section{PROPORTION OF EVER-PARTNERED WOMEN AND GIRLS AGED 15-49 SUBJECTED TO PHYSICAL OR SEXUAL VIOLENCE BY A CURRENT OR FORMER INTIMATE PARTNER IN THE PREVIOUS 12 MONTHS, BY REGION, 2005-2016}

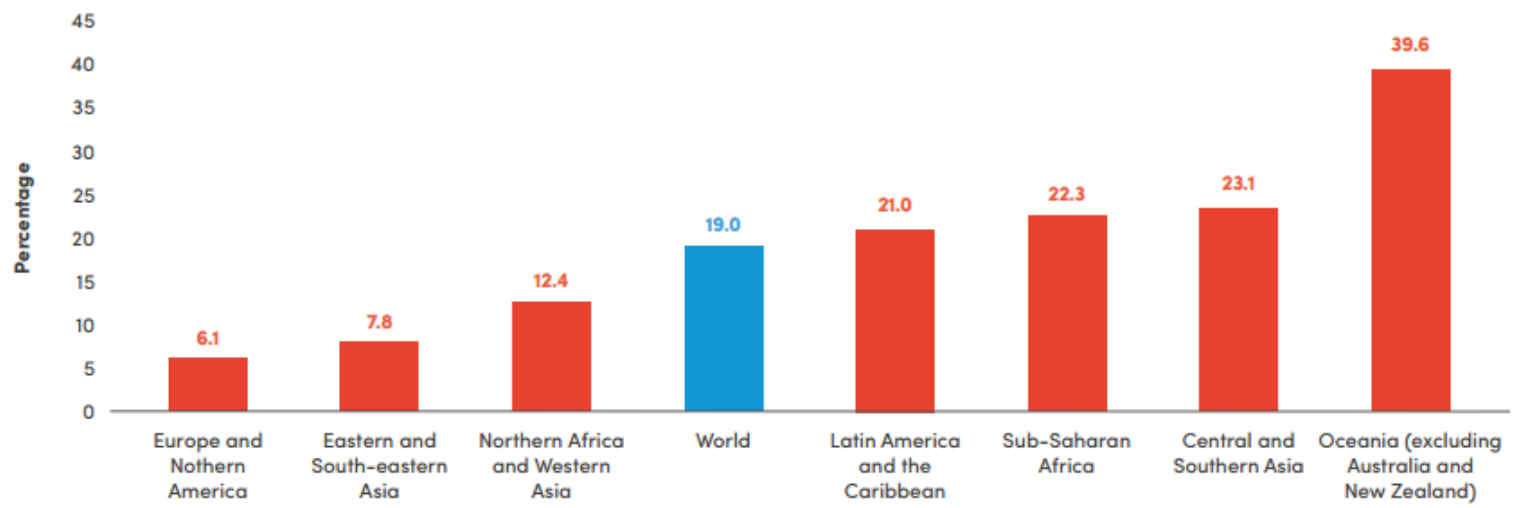

Sumber: (UN Women, 2018)

Dilihat dari tabel persentase di atas, referent object tetaplah perempuan. Namun demikian, ancaman justru berasal dari pasangannya itu sendiri. Jumlah persentasi kekerasan terhadap perempuan sangatlah tinggi. Dintinjau dari aspek regional, lima (5) diantara tujuh (7) wilayah kawasan memiliki indeks kekerasan yang berada di atas 10 persen. Kawasan oseania (termasuk Australia dan Selandia Baru) memiliki jumlah tingkat kekerasan yang sangat tinggi dengan angka persentase 39,6 persen. Dari tabel di atas dapat dianalisis bahwa program P4P yang dijalankan oleh UN Women belum sepenuhnya efektif. Sejumlah kawasan yang ada di dunia masih memiliki tingkat kekerasan yang sangat tinggi terhadap perempuan. Ini menandakan bahwa ancaman yang datang dari pasangan sebagai akibat budaya patriarki yang mengakar belum termitigasi dengan baik. Pekerjaan rumah yang dimiliki oleh UN Women hingga tahun 2016 kemarin masih perlu banyak yang dibenahi.

Tidak hanya itu, program Safe Cities yang dicanangkan oleh UN Women perlu tetap dimonitor dan dievaluasi. Program Safe Cities bertujuan untuk membangun kota yang aman bagi perempuan agar terhindar dari kekerasan di beberapa negara yang dianggap masih sangat rawan. Namun begitu, kekerasan masih tetap terjadi seperti yang tertuang dalam tabel berikut ini: 


\section{FIGURE 3.9}

\section{PROPORTION OF EVER-PARTNERED WOMEN AND GIRLS AGED 15-49 SUBJECTED TO PHYSICAL AND/OR SEXUAL VIOLENCE BY A CURRENT OR FORMER INTIMATE PARTNER IN THE PREVIOUS 12 MONTHS, TREND ANALYSIS, VARIOUS YEARS (2004-2016)}

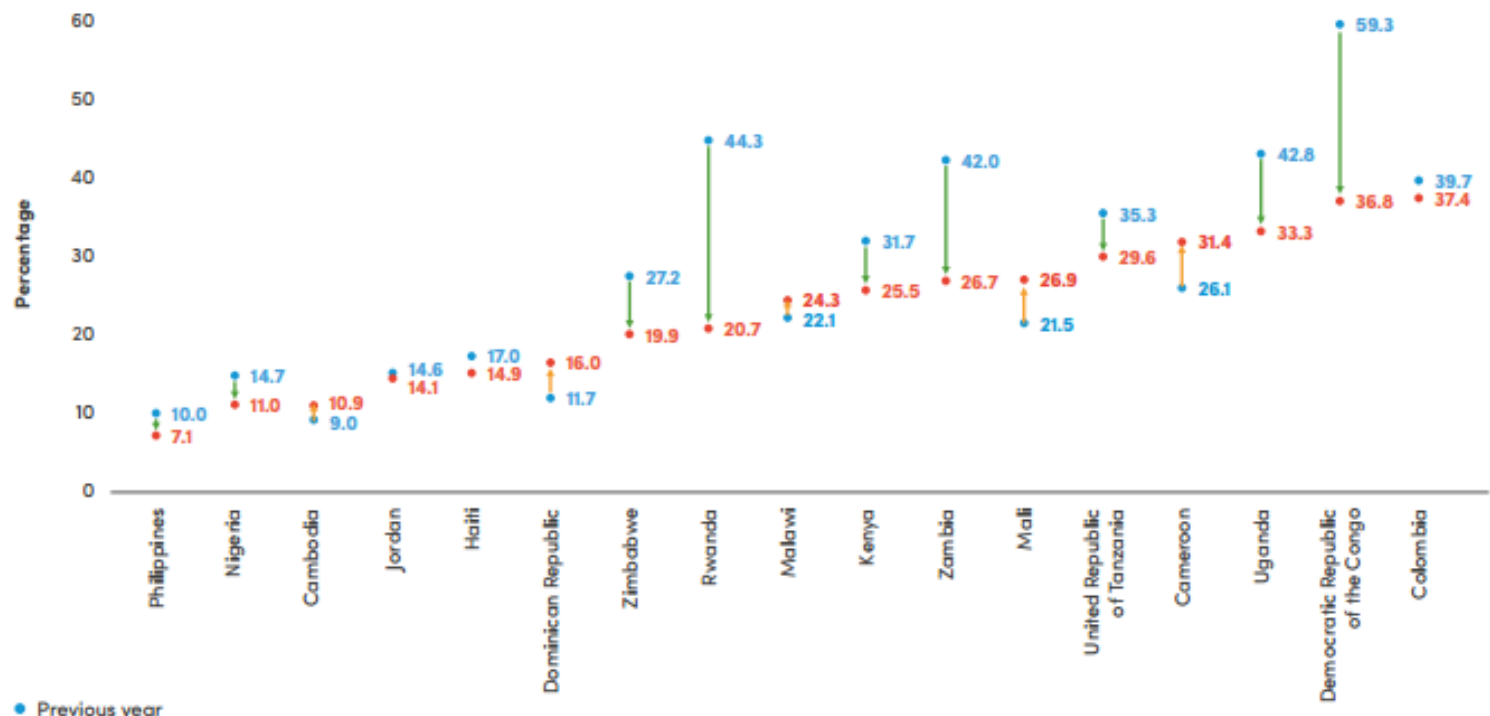

- Latest year

Sumber: (UN Women, 2018)

Berdasarkan data di atas, tingkat kekerasan terhadap perempuan masih sangat tinggi. Salah satu contohnya adalah negara Rwanda. Program Safe Cities yang dicanangkan oleh UN Women salah satunya adalah mengatasi kekerasan terhadap perempuan di negara tersebut. Akan tetapi, persentase kekerasan terhadap perempuan di Rwanda justru meningkat dua kali dari tahun sebelumnya. Peningkatan ini terlihat dari angka persentase dari 20,7 persen menjadi 44,3 persen. Dari sekian banyak negara yang dinilai dari laporan UN Women tersebut, hanya ada tiga negara yang berhasil menurunkan tingkat kekerasan terhadap perempuan yaitu Republik Dominika, Kamerun dan Mali. Sisa negara lainnya masih belum memperlihatkan tingkat penurunan kekerasan terhadap perempuan.

Dua data di atas dapat dianalisis bahwa budaya patriarki sebagai entitas ancaman belum termitigasi dengan baik. Artinya adalah negara-negara di atas masih menempatkan perempuan sebagai identitas inferior. Lembaga UN Women telah berdiri sejak 2010 yang lalu. Walaupun demikian, kekerasan terhadap perempuan masih sangat marak. Tabel persentase di atas menunjukkan bahwa perempuan masih belum menempatkan posisi perempuan setara dengan laki-laki terkait hak asasinya sebagai manusia. Budaya patriarki pada dasarnya mendorong atau menjadi justifikasi bagi laki-laki untuk melakukan kekerasan terhadap perempuan. Sebaliknya, budaya patriarki menempatkan perempuan sebagai referent object dan harus menerima kekerasan karena hal tersebut sudah menjadi hal yang wajar. Pada akhirnya, budaya kekerasan ini akan terus subur karena kekerasan yang berasal dari budaya patriarki tidak dianggap sebagai sebuah ancaman. 
Bagaimana peran UN Women sebagai lembaga tertinggi dunia menjalankan program emansipasinya? Tentu saja ini bukan perkara yang mudah. Kekerasan terhadap perempuan masih dianggap "lumrah" karena secara budaya mereka di bawah laki-laki. UN Women perlu secara rutin membangun kesadaran berpikir pada konstruksi sosial masyarakat bahwa perempuan dan laki-laki memiliki hak yang sama sebagai manusia. Tentunya, UN Women harus secara intens membangun framework bahwa kekerasan fisik ataupun non-fisik terhadap perempuan merupakan bentuk ancaman terhadap identitasnya sebagai manusia. Mengacu pada pendapat Buzan bahwa ketika ancaman sudah sedemikian penting, maka hal tersebut harus segera dilembagakan (Buzan 1998). Artinya adalah UN Women secara konsisten mendorong kekerasan terhadap perempuan sebagai salah satu bentuk ancaman yang mana tingkatannya sama seperti ancaman invasi, perubahan iklim ataupun inflasi ekonomi. Oleh karena itu, program pemberdayaan perempuan dari UN Women perlu diapresiasi. Namun, UN Women masih perlu berupaya keras untuk menghapuskan kekerasan terhadap perempuan.

\section{UN Women dalam Mewujudkan Kesetaraan Gender}

Selain kekerasan yang dilakukan laki-laki terhadap perempuan, kesetaraan gender juga masih menjadi bahasan pokok dalam agenda organisasi-organisasi feminis. Ketimpangan antara laki-laki dan perempuan masih sangat terasa, apalagi perihal pekerjaan. Kontribusi perempuan dalam beberapa aspek juga masih sangat kurang dan seringkali dianggap sebelah mata karena adanya pandangan bahwa perempuan tidak kredibel dan tidak kompeten dalam melakukan beberapa pekerjaan.

Dalam Chapter 5 World Development Report yang berjudul Gender Differences in Employment and Why They Matter yang diterbitkan oleh World Bank pada tahun 2012, dikatakan bahwa pekerjaan laki-laki dan perempuan sangat berbeda. Perubahan dalam struktur pekerjaan karena pembangunan ekonomi tidak cukup untuk menghilangkan segregasi pekerjaan berdasarkan jenis kelamin. Di seluruh dunia, perempuan selalu terkonsentrasi pada pekerjaan dengan produktivitas dan penghasilan yang rendah (World Bank 2012). Padahal tidak sedikit perempuan yang mampu dan dapat dengan baik mengerjakan pekerjaan yang umumnya dilakukan oleh laki-laki. Seperti pekerjaan sebagai pemimpin dalam sebuah perusahaan yang selalu diidentikan dengan laki-laki. Perempuan jarang sekali bisa mencapai jabatan atau posisi yang lebih tinggi dari sebelumnya. Lagi-lagi, pandangan bahwa power laki-laki selalu lebih tinggi daripada power perempuan mempengaruhi fenomena ini.

Lalu dalam hal upah atau penghasilan yang didapatkan oleh perempuan. Dalam penelitian yang dilakukan oleh Wall Street Journal dengan melihat kesenjangan upah antara laki-laki dan perempuan dalam 422 pekerjaan di Amerika Serikat, upah perempuan masih sangat jauh di bawah dibandingkan dengan upah rekan laki-laki mereka. Di Amerika Serikat, perempuan hanya akan mendapatkan sekitar 50-70 sen untuk satu dollar yang didapatkan lakilaki (Iversen 2017). Tentu ini merupakan fakta yang sangat menyedihkan mengingat pekerjaan yang dilakukan perempuan tidak selamanya lebih mudah daripada yang dilakukan laki-laki. Peran perempuan pun tetap harus dilibatkan dan tidak bisa dikesampingkan. Dalam beberapa aspek seperti pembuatan suatu kebijakan atau pengambilan sebuah keputusan, lakilaki tidak bisa berdiri sendiri tanpa melibatkan peran perempuan. Sekalipun kebijakan atau keputusan tersebut hanya ditujukan kepada laki-laki, perempuan pasti akan mengalami side effect mengingat laki-laki dan perempuan akan selalu hidup berdampingan.

Dua poin utama yang menjadi indikator serta tujuan dari eksistensi UN Women yang juga menjadi fokus penulis dalam rangka mewujudkan kesetaraan gender ialah end all forms 
of discrimination against women and girls everywhere dan ensure women's full and effective participation and equal opportunities for leadership at ll levels of decision-making in political, economy and public life. Dua indikator ini memiliki keterkaitan di mana dapat dilihat bahwa dalam menghapuskan segala bentuk diskriminasi yang dirasakan perempuan, keterlibatan atau partisipasi perempuan di ruang publik, terutama dalam proses pengambilan keputusan, perlu ditingkatkan yang mana salah satunya dapat dilakukan dengan membuat kerangka hukum yang mempromosikan non-diskriminasi terhadap gender itu sendiri.

\section{Gambar 1 Peta Negara dengan Kerangka Hukum Non-Diskriminasi}

\footnotetext{
Does nondiscrimination clause mention gender in the constitution?, 2015

Measures whether there is a nondiscrimination clause in the constitution which mentions gender. For the answer to be "Yes," the constitution must use either the word discrimination or the word nondiscrimination or even when there is a "clawback" provision granting exceptions to the nondiscrimination clause for certain areas of the law, such as inheritance, family and customary law.
}

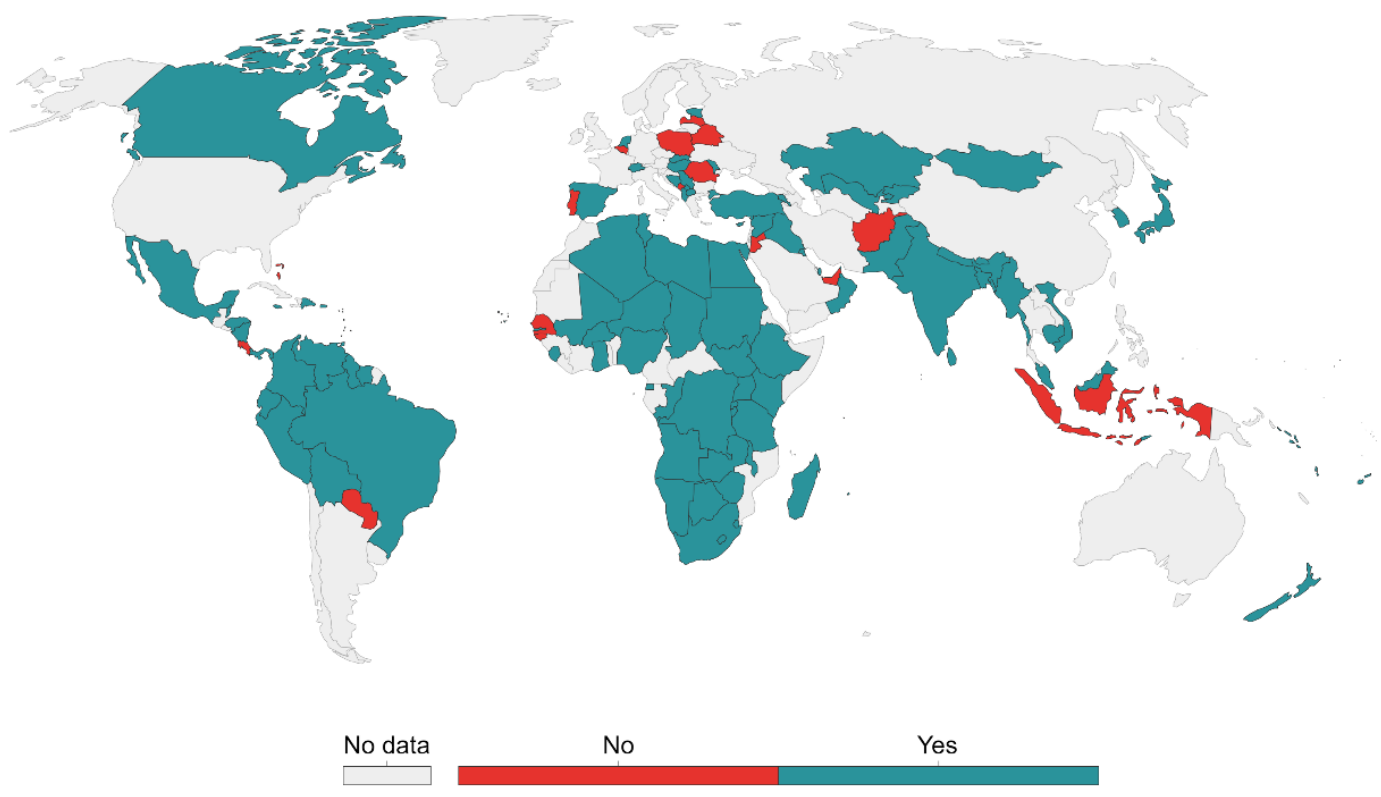

Sumber: (Our World In Data, 2015)

Melalui peta di atas dapat dilibat di tahun 2015 terdapat negara-negara yang masih belum menerapkan hukum ataupun konstitusi larangan diskriminasi terhadap gender. Padahal, apabila mengacu pada salah satu konvensi dalam UN yaikni Convention on the Elimination of All Forms of Discrimination against Women atau CEDAW yang diadopsi oleh UN General Assembly di tahun 1979 dan telah diratifikasi oleh 189 negara anggota UN, maka setidaknya segala bentuk praktik yang mencederai konvensi tersebut, dapat dipertimbangkan sebagai perbuatan yang tidak menghormati HAM. Namun begitu, tidak semua negara secara serta merta memasukan klause non-diskriminasi terhadap perempuan ke dalam konstitusi ataupun hukum domestiknya. Dengan adanya hukum atau konstitusi yang secara eksplisit atau tersurat menyatakan ketidaksetujuan atas diskriminasi yang banyak dialami perempuan, salah satu indikator yang diperjuangkan oleh UN Women dapat lebih mudah tercapai dan diwujudkan.

Selain itu, indikator kedua yakni meningkatkan keterlibatan perempuan bukan hanya dalam politik domestik, melainkan juga dalam ranah politik praktis yang mencakup proses pengambilan keputusan dalam kebijakan publik, keterlibatan perempuan dalam badan hukum 
dan legislatif pun semakin diusungkan di banyak negara. UN Women sendiri banyak mengampanyekan gerakan untuk penambahan kuota perempuan dan women in leadership dalam perusahaan. Walaupun tidak mendapatkan hasil peningkatan yang signifikan karena nyatanya dari 39\% negara di seluruh dunia yang telah menggunakan kuota untuk meningkatkan partisipasi perempuan dalam politik, hanya $23,4 \%$ diantaranya yang anggota parlemen nasionalnya adalah perempuan (UN Women n.d).

Dalam politik praktis, berdasarkan data dari UN sendiri, keterlibatan atau partisipasi perempuan di parlemen naik dari 22,4\% menjadi 25\% di tahun 2015. Jika dikelompokkan berdasarkan kawasan, 19,7\% menteri-menteri di Afrika ialah perempuan. Kemudian Asia dengan $11 \%$ di mana 25,7\% diantaranya didominasi oleh Indonesia karena diantara negaranegara Asia, Indonesia cukup tinggi apresiasi terhadap perempuan dengan mengangkat serta memberi kesempatan terhadap perempuan untuk mengisi posisi sebagai menteri. Sedangkan di negara-negara Arab, jabatan eksekutif perempuan paling banyak di Tunisia dan Uni Emirat Arab. Terakhir, keterlibatan perempuan dalam ranah politik praktis, terutama yang mengisi jabatan kementerian di Eropa ada di angka 22,5\% (UN News Centre 2017). Angka ini tentu perlu diapresasi karena perlahan namun pasti, peluang keterlibatan perempuan semakin besar dan banyak figur perempuan yang dapat menjadi contoh bahwa di luar sana, perempuan pun bisa menjadi sosok yang penting dalam proses pengambilan kepususan yang mana sebelumnya sangat didominasi sekali oleh laki-laki.

Untuk mewujudkannya, salah satu solusi serta program dari UN Women adalah dengan berkolabolasi bersama negara-negara UN untuk mengadakan serta memberikan pelatihan kepada kandidat politik perempuan agar dapat membangun kapailitas mereka sebagai women in power. Selain itu, penyuluhan kepada partai-partai politik agar memberi kesempatan terhadap perempuan dan mendorong generasi muda baik perempuan maupun laki-laki untuk turut terlibat dalam mempromosikan kesetaraan gender terutama dalam proses pengambilan kebijakan publik. Program Women's Leadership and Political Participation ini tentu bukan hanya progam kosong yang hanya menyediakan kerangka normatif saja. UN Women telah membuat perubahan di beberapa negara-negara seperti Kenya, Pakistan, TimorLeste, dan Zimbabwe, yang mana memang sudah terbukti keterlibatan perempuannya telah meningkat. Contoh kecilnya ialah Kenya, di mana dalam pemilu 2013, UN Women berperan dalam memberikan pelatihan kepada setidaknya 900 kandidat perempuan dan membuat program Campaign for Women in Leadership untuk mendorong perempuan dengan hak pilih. Memang tidak mudah untuk mencapai kesetaraan gender dan mewujudkan SDG yang harusnya terpenuhi pada 2030. UN Women sendiri harus meningkatkan upaya lebih untuk merealisasikannya. Namun setidaknya perempuan di seluruh penjuru dunia kini tahu bahwa mereka memiliki tempat dan dapat menjadi apapun yang mereka inginkan tanpa ada barrier bernama gender. Bagaimanapun perempuan dan laki-laki harusnya memiliki dan menerima hak yang sama dalam memilih pekerjaan yang sesuai dengan apa yang dihasratinya. Tidak adil rasanya apabila mengatakan perempuan lebih lemah daripada laki-laki dan digunakan sebagai justifikasi atas larangan perempuan memilih pekerjaan apapun itu.

\section{Kesimpulan}

Sekitar akhir tahun 1980 dan awal tahun 1990-an, lahir sebuah paradigma baru berenama feminisme yang hadir untuk menentang disiplin Ilmu Hubungan Internasional pada saat itu yaitu realisme dan liberalisme. Feminisme sendiri adalah pandangan yang fokus pada ketimpangan antara laki-laki dan perempuan, serta pengaruhnya pada politik dunia. Maka dari 
itu dibuat suatu organisasi dibawah UN yaitu UN Women sebagai bentuk implementasi dari feminisme dan untuk memerjuangkan hak-hak perempuan. Fokus utama UN Women adalah mengatasi kekerasan terhadap perempuan yang kerap dilakukan laki-laki dan mewujudkan kesetaraan gender yang merupakan salah satu SDG yang harus tercapai pada 2030. UN Women sendiri sudah cukup berhasil serta efektif dalam menjalankan program untuk mengatasi kekerasan gender dan mengatasi ketimpangan serta diskriminasi terhadap perempuan. Efektivitas ini dapat dilihat dari sejumlah program yang berusaha dikembangkan oleh UN Women seperti program Safe Cities untuk mengatasi keamanan perempuan yang kerap dijadikan korban kekerasan dan program Women's Leadership and Political Participation untuk mendoorng keterlibatan perempuan dalam politik praktis dan proses pengambilan keputusan. Dua program ini secara tidak langsung berusaha menghapuskan peran-peran yang sebelumnya sangat didominasi oleh laki-laki dan membuat keamanan serta peluang terhadap perempuan semakin terbuka. 


\section{REFERENSI}

\section{Buku}

Jackson, R., and Sorensen, G. (2013). Introduction to International Relations ${ }^{\text {th }}$ ed.). United Kingdom: Oxford University Press.

Hannam, J. Power: Women, Politics, and Power in Europe after 1920. In Connor, L. (2016). A Cultural History of Women in Modern Age. United Kingdom: Bloomsbury Academic

Shimko, K. (2013). International Relations: Perspectives, Controversies, and Readings ( $^{\text {th }}$ ed.). United States: Wadsworth Cengage Learning.

Tickner, A., and Sjoberg, L. Feminism. In Dunne, T., Kurki, M., and Smith, S. (2016). International Relations Theories: Discipline and Diversity ( $4^{\text {th }}$ ed.). United Kingdom: Oxford University Press.

Viotti, Paul R. and Kauppi, Mark V. (2014). International Relations Theory 5th Edition. England: Pearson.

\section{Jurnal}

Hirschmann, N. (1989). Freedom, Recognition, and Obligation: A Feminist Approach to Political Theory. In Sinopoli, R., and Hirschmann, N. (1991). Feminism and Liberal Theory. The American Political Science and Review, Vol. 85(1), 221-233. Retrieved from http://www.jstor.org/stable/1962887?seq=1\#page_scan_tab_contents

Sinopoli, R., and Hirschmann, N. (1991). Feminism and Liberal Theory. The American Political Science and Review, Vol. 85(1), 221-233. Retrieved from http://www.jstor.org/stable/1962887?seq=1\#page_scan_tab_contents

\section{Internet}

Domingo, P. (2013). Evaluation of UN Women's Contribution to Increasing Women's Leadership and Participation in Peace and Security and Humanitarian Response dalam Headquarter and Global Case Study. Headquarter and Global Case Study. Retrieved from https://www.odi.org/sites/odi.org.uk/files/odi-assets/publicationsopinion-files/89 66.pdf

Falconer, C. (2017). Women Workers and Exploitation: the Gender Pay Gap is Just the Beginning. Focus on Labour Exploitation. Retrieved from http://www.labourexploitation.org/news/women-workers-and-exploitation-genderpay-gap-just-beginning

Iversen, K. (2017). 7 Charts that Show Gender Inequality Around the World. World Economic Forum. Retrieved from https://www.weforum.org/agenda/2017/08/chartsgender-inequality-women-deliver

London Feminist Network. (n.d). What is Patriarchy?. Retrieved from http://londonfeministnetwork.org.uk/home/patriarchy

Our World in Data. (2015). Does Discrimination Clause Mention Gender in the Constitution?. Retrieved from https://ourworldindata.org/grapher/nondiscriminationclause-gender 
The Organisation for Economic Co-operation and Development. (2015). Development Effectiveness Review of the United Nations Entity for Gender Equality and the Empowerment for Women (UN Women). Retrieved from https://www.oecd.org/derec/netherlands/UNWOMEN-Review-Final-Report-April2015 .pdf

United Nations. (n.d). Goal 5: Achieve Gender Equality and Empower All Women and Girls. Retrieved from http://www.un.org/sustainabledevelopment/gender-equality/

------ (n.d). Funds Programmes, Specialized Agencies and Others. Retrieved from http://www.un.org/en/sections/about-un/funds-programmes-specialized-agencies-andothers/

(2017). Women's Political Parity Slow to Grow as UN Launches Latest 'Women in Politics' Map. Retrieved from https://www.un.org/sustainabledevelopment/ blog/2017/03/womens-political-parity-slow-to-grow-as-un-launches-latest-women-inpolitics-map/

UN Women. (2015). Monitoring Gender Equality and Empowerment of Women and Girls in the 2030 Agenda for Sustainable Development: Opportunities and Challenges. Retrieved from http://www.unwomen.org/en/digital-library/publications/2015/9/ indicators-position-paper

(2018). Turning Promises Into Action: Gender Equality in the 2030 Agenda for Sustainable Development. Retrived from http://www.unwomen.org/en/digitallibrary/publications

------ (n.d). Convention on the Elimination of All Forms of Discrimination against Women. Retrieved from http://www.un.org/womenwatch/daw/cedaw/

(n.d). About UN Women. Retrieved from http://www.unwomen.org/en/about-us/aboutun-women

(n.d). Peace and Security. Retrieved from http://www.unwomen.org/en/what-wedo/peace-and-security

(n.d). Economic Empowerment. Retrieved from http://www.unwomen.org/en/ what-wedo/economic-empowerment

----- (n.d). Governance and National Planning. Retrieved from http://www.unwomen.org/ en/ what-we-do/governance-and-national-planning

----- (n.d). Ending Violence against Women. Retrieved from http://www.unwomen. org/en/what-we-do/ending-violence-against-women

(n.d). Creating Safe Public Spaces. Retrieved from http://www.unwomen.org/ en/whatwe-do/ending-violence-against-women/creating-safe-public-spaces

(n.d). SDG 5: Achieve Gender Equality and Empower All Women and Girls. Retrieved from http://www.unwomen.org/en/news/in-focus/women-and-the-sdgs/sdg-5-genderequality

----- (2018). Turning Promises Into Action: Gender Equality in the 2030 Agenda for Sustainable Development. Retrived from http://www.unwomen.org/en/digitallibrary/publications

World Health Organization. (2017). Violence against Women Fact Sheet. Retrieved from http://www.who.int/mediacentre/factsheets/fs239/en/

World Bank. (2012). Gender Differences in Employment and Why They Matter. World Development Report 2012. Retrieved from http://siteresources.worldbank.org/ INTWDR2012/Resources/7778105-1299699968583/77862101315936222006/chapter-5.pdf 